\title{
Phytoremediation potential of two maize varieties cultivat- ed on metal-particulate-contaminated soil
}

\author{
M. B. ADEWOLE*, B. O. OYEBANJI \& K. IGBEKELE \\ (M.B.A \& K.I.: Institute of Ecology and Environmental Studies, Obafemi Awolowo University, \\ Ile-Ife, Nigeria; B.O.O.: Department of Animal Science, Obafemi Awolowo University, Ile-Ife, \\ Nigeria) \\ *Corresponding author's email: mbadewole@gmail.com/badewole@oauife.edu.ng
}

\begin{abstract}
Arbitrary cultivation of vacant land, even within the periphery of cottage industries in developing countries, particularly in Nigeria, is on the increase. Two maize varieties [ART98/SW1 (protein) and BR-9928-DMR-SR-Y (non-protein)] were planted within the vicinity of a metal recycling plant in Ile-Ife, Nigeria to assess the metal removal potentials of these maize cultivars. The experiment was conducted in two locations, each per maize variety and laid out in a randomised complete block design. Two biochars produced from maize stover and Milicia exelsa, each at $10 \mathrm{t} \mathrm{ha}^{-1}$ were used as soil amendments. Metal uptake by the two maize varieties was in the order: root $>$ shoot $>$ grain, with protein maize having higher bioconcentration factors: $\mathrm{Fe}$

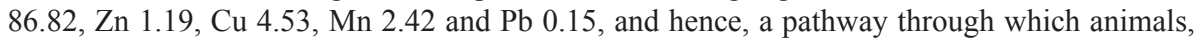
including humans could ingest these metals. It was concluded that maize crop is a bioaccumulator of metals in soil, and protein maize cultivar removes more metals than non-protein maize.
\end{abstract}

Keywords: Biochar; farm waste; heavy metal; maize; particulate matter; remediation. Original scientific paper. Received 15 Apr 2018; revised 29 May 2019

\section{Introduction}

Presently in Nigeria, peri-urban agriculture is increasing. This trend in agri-business enhances the cultivation of many vacant lands with arable crops such as cereals and vegetables. Many of such lands are within the vicinity of industries whose surrounding soils are contaminated with the untreated wastewater and particulate matter they generate, and which contain heavy metals in their organic or inorganic forms. Other sources of heavy metals in soil include mining, repeated application of sewage sludge, municipal wastes and impurities in fertilizers (Wang et al., 2003). Heavy metals are extremely persistent in the soil environment because they are not biodegradable and may not be broken down by chemical methods (Adewole et al., 2009) or through thermal processes; as a result, their accumulation could reach toxic levels (Bohn et al., 1985).

Although, trace amounts of these heavy metals such as Selenium (Se), Arsenic (As), Chromium (Cr), Copper ( $\mathrm{Cu})$ and Zinc $(\mathrm{Zn})$ are required by living organisms, but become extremely toxic above certain threshold levels (Panda \& Choudhury, 2005) and very detrimental to human health (Amdur et al., 1991; Pirkle et al., 1998). Series of these associated risks to

Ghana Jnl Agric. Sci. 54 (1), 38 - 46

GJAS is an Open Access Journal and distributed under the terms of the Creative Commons (CC) License [CC BY 4.0] 
cultivating heavy metal-contaminated soil to food crops, therefore requires reclamation of such soils using any of the environment-friendly biotechnology approaches. Phytoremediation is one of the promising methods for reclamation of soils contaminated with toxic metals by using hyperaccumulator plants (Cui et al., 2007). Maize (Zea mays) (Wang et al., 2007), oat (Avena sativa) (Tanhuanpaa et al., 2007), Viola baoshanensis (Liu et al., 2004; Zhuang et al., 2007), sunflower (Helianthus annuus) (Tandy et al., 2006) and rice (Oryza sativa) (Murakami et al., 2007) are common and important agricultural crops worldwide that have been used in many studies of metal pollution.

The capability of the plant to uptake the contaminants, ability of the plant to survive in the contaminated soil and bioavailability of the contaminants in the soil are some of the limiting factors which influence phytoremediation efficiency. Phytoremediation can be enhanced either by increasing the capability of contaminant uptake of the plant or by amending the soil to increase the bioavailability of the contaminants. Some studies aimed at enhancement of phytoremediation by improving the contaminant mobility and bioavailability in soils by adding suitable chelating agents or surfactants (Prasad \& Freitas, 2003; Yanshan et al., 2006). Synthetic chelating agents such as ethylene diamine tetra acetate (EDTA) have been used to artificially enhance the solubility of heavy metals from the soil solid phase to the soil solution and thus increase heavy metal phyto availability (Luo et al., 2007; Epelde et al., 2008). Addition of chelating agents to soil may promote root uptake and translocation from the roots to harvestable above-ground parts of crops with high biomass production (Huang et al., 1997). But in such cases, there is a possibility of contamination of the soil and groundwater by the chemicals used for mobilizing the contami- nants. Also, the mobilized contaminants can migrate to the groundwater, thus contaminating the groundwater and spreading the contamination. Biomass improvement is another way of improving phytoremediation. By improving the growth response, the water and nutrient uptake of the plants will be increased and this could lead to increased contaminant uptake.

Biochar, a pyrolysed carbon-rich product of biomass (Lehmann et al., 2011) has the potential to increase soil nutrients (Masulili et $a l ., 2010)$ and also has strong adsorption capacity (Steiner et al., 2008) and are mostly alkaline (Ilesanmi et al., 2016). Presently in Nigeria, the cultivation of improved varieties of maize is increasing. A lot of contaminated soils are therefore being inadvertently put into maize cultivation, despite the inherent metal removal potential of maize from contaminated soils. However, there is dearth of information on the remedial and bio-accumulating potential of protein (ART98/SW1) and non-protein (BR9928-DMR-SR-Y) maize cultivars when they are cultivated on metal-contaminated soil with biochars as soil enhancers, hence this study.

\section{Materials and methods}

Experimental location, design and agronomic practices

This was a field study conducted in the late maize cropping season (August to November) of 2015 on an Ultisols and Iwo series farmland $\left(07^{\circ} 29.714^{\prime} \mathrm{N}, 004^{\circ} 28.658^{\prime} \mathrm{E}\right.$ and $262 \mathrm{~m}$ above sea level) within the vicinity of a Metal Recycling Plant, Ile-Ife, Nigeria. Iron and steel scraps that could have constituted environmental hazards are the major raw materials being recycled by this recycling plant (Owoade et al., 2013) and this study location was purposively chosen. The experimental plot was manually cleared twice and the topsoil loosened using a hand-held hoe. Three representative compos- 
ite soil samples for pre-cropped soil test to the depth $0-15 \mathrm{~cm}$ were taken using soil auger. The soil samples were air-dried, sieved using 2.0 $\mathrm{mm}$ mesh and stored for laboratory analysis.

The experimental plot size was $11.0 \mathrm{~m} \times 15.0$ $\mathrm{m}$ which was further divided into four equal block sizes of $11.0 \mathrm{~m} \times 3.0 \mathrm{~m}$ with an alley of $1.0 \mathrm{~m}$ between blocks and $1.0 \mathrm{~m}$ within blocks. Each of the blocks was divided into four equal sub-plots, each measuring $2 \mathrm{~m} \times 3 \mathrm{~m}$ to give a total of 16 sub-plots arranged in a randomized complete block design for each maize cultivar. The viable seeds of the two maize varieties [ART98/SW1 (protein maize) and BR-9928-DMR-SR-Y (non-protein maize)] obtained from the Institute of Agricultural Research and Training (IAR \& T), Ibadan, Nigeria were sown at three seeds per hill using 75 $\mathrm{cm} \times 50 \mathrm{~cm}$ planting distance to the depth of 3 $\mathrm{cm}$. The two biochars made from maize stover and Milicia exelsa were applied at planting as soil amendments. The treatments were made up of the maize with $100 \%$ maize stover (MS), $100 \%$ M. exelsa $(\mathrm{ME}), 50 \% \mathrm{MS}+50 \% \mathrm{ME}$, and each at the rate of ten tonnes per hectare as treatments. Zero biochar application served as control. The maize seedlings were thinned to two stands per hole at 2 weeks after sowing (WAS) and all the plots were manually weeded using hand-held hoe thrice at 2, 5 and 7 WAS. The maize grains were manually harvested at 12 WAS, sun-dried, shelled and stored for laboratory analysis.

Sample collection, preparation and laboratory analyses

Post-cropped composite soil samples to the depth $0-15 \mathrm{~cm}$ were taken using soil auger from each of the plots, air-dried and sieved using $2.0 \mathrm{~mm}$ mesh for selected soil properties determination. Also, six of the maize plants in each plot that had earlier been randomly se- lected and tagged were manually cut using a clean and sharp kitchen knife and their roots were carefully dug up using a hand-held hoe and thereafter rinsed with deionised water to remove dirt. The plant tissues were put in separate envelopes, oven-dried at $70^{\circ} \mathrm{C}$ to a constant weight, milled using stainless-steel Thomas milling machine and sieved using 0.5 $\mathrm{mm}$ mesh for the determination of heavy metal concentrations in the roots, shoots and grains of the maize crop.

Selected soil physical and chemical properties were determined using standard methods as contained in Page et al. (1982). Soil $\mathrm{pH}$ was potentiometrically determined in a 1:1 soil: $1 \mathrm{M} \mathrm{KCl}$ using the Dwyer model WPH1 waterproof $\mathrm{pH}$ tester. Particle size distribution was determined using the hydrometer method and 5\% sodium hexametaphosphate as the dispersing agent. For extraction for heavy metals in the soil samples, $5 \mathrm{ml}$ of the mixture of concentrated $\mathrm{HNO}_{3}$ and $\mathrm{HClO}_{4}$ in the ratio $2: 1$, and $5 \mathrm{ml}$ of concentrated $\mathrm{H}_{2} \mathrm{SO}_{4}$ was used to digest $0.5 \mathrm{~g}$ of each soil sample for $2 \mathrm{~h}$ at $150^{\circ} \mathrm{C}$. The soil digest was allowed to cool and thereafter diluted with distilled water to make up to $25 \mathrm{ml}$. Concentrations of $\mathrm{Mn}, \mathrm{Ni}, \mathrm{Cu}, \mathrm{Zn}$, $\mathrm{Fe}, \mathrm{Cd}$ and $\mathrm{Pb}$ in the soil extracts were read on Buck Scientific 210/211 VGP Atomic Absorption Spectrophotometer (AAS) (East Norwalk, Connecticut, USA). For the sieved plant tissues, $0.5 \mathrm{~g}$ each was digested using $5 \mathrm{ml}$ of the mixture of concentrated $\mathrm{HNO}_{3}$ and $\mathrm{HClO}_{4}$ in the ratio $2: 1$, and $5 \mathrm{ml}$ of concentrated $\mathrm{H}_{2} \mathrm{SO}_{4}$, allowed to cool and each diluted with distilled water to make up to $25 \mathrm{ml}$. Concentrations of $\mathrm{Mn}, \mathrm{Ni}, \mathrm{Cu}, \mathrm{Zn}, \mathrm{Fe}, \mathrm{Cd}$ and $\mathrm{Pb}$ in each plant extracts were read on AAS.

\section{Data analyses}

Bioconcentration factor (BCF) was determined through the ratio of the concentration of met- 
al in the roots to that in the soil (Yoon et al., 2006).

$\mathrm{BCF}=[\mathrm{M}]_{\text {roots }} /[\mathrm{M}]_{\text {soil }}$

Where:

$[\mathrm{M}]_{\text {roots }}=$ concentration of the metal in the roots $[\mathrm{M}]_{\text {soil }}=$ concentration of the metal in the soil BCF was used to estimate the plant's ability to accumulate metal in the roots so as to determine the potential of the plants for phytoremediation (Yoon et al., 2006).

Translocation factor (TF) was calculated as the ratio of metal concentration in the shoots to metal concentration in the roots (Yoon et al., 2006).

$\mathrm{TF}=[\mathrm{M}]_{\text {shoots }} /[\mathrm{M}]_{\text {roots }}$

Where:

$[\mathrm{M}]_{\text {shoots }}=$ metal concentration in the shoots

$[\mathrm{M}]_{\text {roots }}=$ metal concentration in the roots

TF was used to estimate the plant's ability to translocate metals from the roots to aboveground parts. Also, a one-way analysis of variance (ANOVA) was conducted to determine the effects of biochar type on the metal concentrations in each of the maize plant's parts (roots, shoot and grains). Duncan's Multiple Range Test (SAS version 9.1) at 95\% probability level was used to test for significant differences between individual means of metal concentrations.

\section{Results and discussion}

The pre-cropped soil results are presented in Table 1. The soil $\mathrm{pH}$ of 5.32 in $1: 1$ soil- $\mathrm{H}_{2} \mathrm{O}$ ratio was an indication that the soil was acidic. Also, the particle size proportion of sand 754.00 , silt 130.00 and clay $116.00 \mathrm{mg} \mathrm{kg}{ }^{-1}$ obtained indicated a loamy sand soil texture. Concentrations of heavy metals: $\mathrm{Fe}, \mathrm{Zn}, \mathrm{Cu}$, $\mathrm{Ni}, \mathrm{Mn}, \mathrm{Pb}$ and $\mathrm{Cd}$ were 2133.80, 787.75, $59.81,31.80,455.85,36.44$ and $2.00 \mathrm{mg} \mathrm{kg}{ }^{-1}$ respectively. These values were comparable to those obtained by Adeyeye et al. (2016) who had earlier worked within the same study location while measuring the particulate matter in the ambient air.

Relatively high soil acidity of the study site will enhance the solubility and mobility of these metals. Generally, soluble and mobile soil nutrients are taken up by the roots of the growing plants by interception and osmotic pull approach. In addition to plant nutrients requirement, these metals are also picked up by maize. The concentration of metals in the test crops as influenced by biochar applications are presented in Tables 2 and 3. Except for Fe, Ni and $\mathrm{Mn}$, roots of protein maize from the control

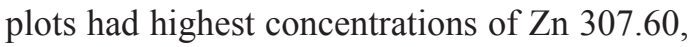
$\mathrm{Cu} 44.47$ and $\mathrm{Pb} 23.06 \mathrm{mg} \mathrm{g}^{-1}$. Comparable but lower values were obtained in the roots of non-protein maize. Many of these soluble and positively charged cations are adsorbed to the biochar surface. Mohan et al. (2007) and Steiner et al. (2008) observed a similar attribute of biochars in metal adsorption capability.

From the results, the concentration of metals in the roots, shoots and grains of the two maize varieties cultivated on the metal-contaminated soil, it was observed that metals differed considerably in uptake from each other with Fe having the highest uptake concentration values. Lead was only detected in roots while $\mathrm{Cd}$ was not detected in any of the maize plants studied. Varietal differences in maize and differences in the Chemistry of these metals could be the cause. This observation was comparable to Khairul et al. (2015) who among other metals studied, observed the highest accumulation of $\mathrm{Fe}$ but lowest for $\mathrm{Cu}$ in maize crops planted on metal-contaminated soil. 
TABLE 1

\begin{tabular}{ll}
\multicolumn{2}{l}{ Physical and chemical properties of pre-cropped soil } \\
\hline Property & Value \\
\hline Soil pH $\left(1: 1 \mathrm{soil}^{\mathrm{H}} \mathrm{H}_{2} \mathrm{O}\right)$ & 5.32 \\
Organic $\mathrm{C}\left(\mathrm{g} \mathrm{kg}^{-1}\right)$ & 9.40 \\
Total N $\left(\mathrm{g} \mathrm{kg}^{-1}\right)$ & 1.00 \\
$\mathrm{Heavy}$ metals $\left(\mathrm{mg} \mathrm{kg}^{-1}\right)$ & \\
$\mathrm{Fe}$ & 2133.80 \\
$\mathrm{Zn}$ & 787.75 \\
$\mathrm{Cu}$ & 59.81 \\
$\mathrm{Ni}$ & 31.80 \\
$\mathrm{Mn}$ & 455.85 \\
$\mathrm{~Pb}$ & 36.44 \\
$\mathrm{Cd}$ & 2.00 \\
Particle size $\left(\mathrm{g} \mathrm{kg}^{-1}\right)$ & \\
Sand & 754.00 \\
Silt & 130.00 \\
Clay & 116.00 \\
Soil texture & Loamy Sand \\
\hline
\end{tabular}

TABLE 2

Concentrations of metals in protein maize as influenced by different treatments of biochars

\begin{tabular}{rlrrrr}
\hline Metal & Protein maize & \multicolumn{4}{c}{ Treatments $\left(\mathrm{mg} \mathrm{g}^{-1}\right)$} \\
& & \multicolumn{1}{c}{$B$} & \\
$\mathrm{Fe}$ & Root & $10043.00 \mathrm{a}$ & $12558.00 \mathrm{a}$ & $10662.00 \mathrm{a}$ & $6102.00 \mathrm{~b}$ \\
& Shoot & $159.10 \mathrm{a}$ & $199.30 \mathrm{a}$ & $168.90 \mathrm{a}$ & $163.19 \mathrm{a}$ \\
& Grain & $54.47 \mathrm{~b}$ & $65.61 \mathrm{~b}$ & $58.10 \mathrm{~b}$ & $89.09 \mathrm{a}$ \\
$\mathrm{Zn}$ & Root & $206.00 \mathrm{~b}$ & $294.30 \mathrm{a}$ & $235.40 \mathrm{~b}$ & $307.60 \mathrm{a}$ \\
& Shoot & $161.40 \mathrm{~d}$ & $231.00 \mathrm{a}$ & $184.60 \mathrm{c}$ & $226.30 \mathrm{~b}$ \\
& Grain & $39.69 \mathrm{c}$ & $57.69 \mathrm{ab}$ & $46.00 \mathrm{bc}$ & $61.39 \mathrm{a}$ \\
$\mathrm{Cu}$ & Root & $20.45 \mathrm{a}$ & $31.71 \mathrm{a}$ & $19.54 \mathrm{a}$ & $44.47 \mathrm{a}$ \\
& Shoot & $1.63 \mathrm{~b}$ & $2.57 \mathrm{ab}$ & $1.54 \mathrm{~b}$ & $2.73 \mathrm{a}$ \\
& Grain & $2.36 \mathrm{a}$ & $3.64 \mathrm{a}$ & $2.39 \mathrm{a}$ & $3.57 \mathrm{a}$ \\
$\mathrm{Ni}$ & Root & $13.27 \mathrm{~b}$ & $19.73 \mathrm{a}$ & $13.21 \mathrm{~b}$ & $14.60 \mathrm{~b}$ \\
& Shoot & $13.76 \mathrm{~b}$ & $18.35 \mathrm{~b}$ & $13.78 \mathrm{~b}$ & $24.63 \mathrm{a}$
\end{tabular}


Phytoremediation potential of two maize varieties...

\begin{tabular}{rlrrrr}
$\mathrm{Mn}$ & Root & $236.30 \mathrm{a}$ & $294.20 \mathrm{a}$ & $228.90 \mathrm{a}$ & $290.30 \mathrm{a}$ \\
& Shoot & $24.60 \mathrm{a}$ & $30.18 \mathrm{a}$ & $24.12 \mathrm{a}$ & $29.54 \mathrm{a}$ \\
$\mathrm{Pb}$ & Grain & $7.05 \mathrm{bc}$ & $8.75 \mathrm{a}$ & $6.78 \mathrm{c}$ & $7.48 \mathrm{~b}$ \\
& Root & $9.25 \mathrm{~b}$ & $14.68 \mathrm{~b}$ & $8.96 \mathrm{~b}$ & $23.06 \mathrm{a}$ \\
& Shoot & nd & nd & nd & nd \\
$\mathrm{Cd}$ & Grain & nd & nd & nd & nd \\
& Root & nd & nd & nd & nd \\
& Shoot & nd & nd & nd & nd \\
& Grain & nd & nd & nd & nd \\
\hline
\end{tabular}

Means with the same letters in each row are not significantly different by Duncan's Multiple Range Test at $\mathrm{p}<$ 0.05. Legend: $\mathrm{A}=100 \%$ maize stover; $\mathrm{B}=100 \%$ Milicia exelsa; $\mathrm{AB}=$ maize stover $50 \%+50 \%$ Milicia exelsa; $\mathrm{C}=$ Control; $\mathrm{nd}=$ not detected

TABLE 3

Concentrations of metals in non-protein maize as influenced by different treatments of biochars

\begin{tabular}{|c|c|c|c|c|c|}
\hline \multirow[t]{2}{*}{ Metal } & \multirow{2}{*}{$\begin{array}{l}\text { Non-protein } \\
\text { maize }\end{array}$} & \multicolumn{4}{|c|}{ Treatments $\left(\mathrm{mg} \mathrm{g}^{-1}\right)$} \\
\hline & & $A$ & $A B$ & $C$ & \\
\hline \multirow[t]{3}{*}{$\mathrm{Fe}$} & Root & $5965.00 \mathrm{a}$ & $5735.00 \mathrm{c}$ & $5847.00 \mathrm{~b}$ & $2989.00 \mathrm{~d}$ \\
\hline & Shoot & $221.30 \mathrm{a}$ & $212.50 \mathrm{a}$ & $216.60 \mathrm{a}$ & $223.30 \mathrm{a}$ \\
\hline & Grain & $61.15 \mathrm{a}$ & $58.77 \mathrm{c}$ & $59.78 b$ & $62.09 \mathrm{a}$ \\
\hline \multirow[t]{3}{*}{$\mathrm{Zn}$} & Root & $225.10 \mathrm{a}$ & $216.90 \mathrm{~b}$ & $231.10 \mathrm{a}$ & $233.10 \mathrm{a}$ \\
\hline & Shoot & $264.70 \mathrm{a}$ & $254.50 \mathrm{a}$ & $269.60 \mathrm{a}$ & $265.50 \mathrm{a}$ \\
\hline & Grain & $67.18 \mathrm{a}$ & $64.54 \mathrm{a}$ & $68.42 \mathrm{a}$ & $47.40 \mathrm{~b}$ \\
\hline \multirow[t]{3}{*}{$\mathrm{Cu}$} & Root & $34.17 \mathrm{a}$ & $28.43 b$ & $30.42 \mathrm{ab}$ & $34.20 \mathrm{a}$ \\
\hline & Shoot & $5.07 \mathrm{a}$ & $4.24 \mathrm{a}$ & $4.52 \mathrm{a}$ & $3.49 \mathrm{a}$ \\
\hline & Grain & $2.05 \mathrm{~b}$ & $1.73 \mathrm{c}$ & $1.83 \mathrm{c}$ & $2.44 \mathrm{a}$ \\
\hline \multirow[t]{3}{*}{$\mathrm{Ni}$} & Root & $18.37 \mathrm{a}$ & $15.31 \mathrm{a}$ & $16.26 \mathrm{a}$ & $19.07 \mathrm{a}$ \\
\hline & Shoot & $20.41 b$ & $17.02 \mathrm{c}$ & $18.03 \mathrm{bc}$ & $22.15 a$ \\
\hline & Grain & $20.60 \mathrm{a}$ & $17.34 \mathrm{c}$ & $18.40 \mathrm{~b}$ & $10.43 d$ \\
\hline \multirow[t]{3}{*}{$\mathrm{Mn}$} & Root & $253.30 \mathrm{a}$ & $219.20 \mathrm{~b}$ & $241.30 \mathrm{a}$ & $123.30 \mathrm{c}$ \\
\hline & Shoot & $56.48 \mathrm{a}$ & $50.53 \mathrm{a}$ & $55.22 \mathrm{a}$ & $49.41 \mathrm{a}$ \\
\hline & Grain & $10.14 \mathrm{a}$ & $8.76 \mathrm{ab}$ & $9.67 \mathrm{a}$ & $7.21 \mathrm{~b}$ \\
\hline \multirow[t]{3}{*}{$\mathrm{Pb}$} & Root & nd & nd & nd & nd \\
\hline & Shoot & nd & nd & nd & nd \\
\hline & Grain & nd & nd & nd & nd \\
\hline \multirow[t]{3}{*}{$\mathrm{Cd}$} & Root & nd & nd & nd & nd \\
\hline & Shoot & nd & nd & nd & nd \\
\hline & Grain & nd & nd & nd & nd \\
\hline
\end{tabular}


Means with the same letters in each row are not significantly different by Duncan's Multiple Range Test at $\mathrm{p}<$ 0.05. Legend: $\mathrm{A}=100 \%$ maize stover; $\mathrm{B}=100 \%$ Milicia exelsa; $\mathrm{AB}=$ maize stover $50 \%+50 \%$ Milicia exelsa; $\mathrm{C}=$ Control; $\mathrm{nd}=$ not detected

Translocation and bioconcentration factors of selected metals for the two maize varieties are presented in Table 4. Only Ni had translocation factor (TF) greater than 1 for protein maize, while $\mathrm{Zn}$ and Ni had TF greater than 1 for non-protein maize variety. This showed that the two maize varieties had better ability to bioaccumulate metals from soil to the root than translocating them from root to the shoot of the maize plant. The implication of this is maize roots are more active in metal extraction from metal-contaminated soils than other plant parts (Cho-Ruk et al., 2006). Except for Zn with bioconcentration factor (BCF) 0.87 in non-protein maize, other metals had BCF greater than 1 in the two maize varieties, though protein maize values were greater. Bioconcentration factor was not estimated for $\mathrm{Cd}$ in protein maize and for $\mathrm{Pb}$ and $\mathrm{Cd}$ in non-protein maize as the metals were not detected in the roots. Hence, the two maize cultivars have bioaccumulating potentials. Yoon et al. (2006) earlier observed that plants exhibiting $\mathrm{BCF}$ values greater than 1 are suitable for phytoextraction. Metal concentrations in the post-cropped soils are presented in Table 5. The metals had lower values in the post-cropped soil than the pre-cropped, thus revealing the phytoextraction ability of the test crop. Generally, the $\mathrm{Fe}, \mathrm{Zn}, \mathrm{Cu}, \mathrm{Ni}$ and $\mathrm{Mn}$ concentrations in the maize grains were lower when compared to the roots and shoots in both protein and non-protein maize varieties when biochars were applied than the control. Lima et al. (2014) reported that key biochar properties such as surface area, $\mathrm{pH}$, ash and carbon contents can be affected by post-treatments and thus enhance biochars' ability to immobilise heavy metals. The metal uptake in both maize varieties was in the order: root $>$ shoot $>$ grain.
TABLE 4

Bioconcentration and translocation factors of selected metals for the maize varieties

\begin{tabular}{lcccc}
\hline Metal & \multicolumn{3}{c}{ Translocation Factor } & \multicolumn{2}{c}{ Bioconcentration Factor } \\
& Protein & Non-protein & Protein & Non-protein \\
\hline $\mathrm{Fe}$ & 0.03 & 0.05 & 86.82 & 59.41 \\
$\mathrm{Zn}$ & 0.68 & 1.32 & 1.19 & 0.87 \\
$\mathrm{Cu}$ & 0.08 & 0.16 & 4.53 & 3.75 \\
$\mathrm{Ni}$ & 1.26 & 1.34 & 1.30 & 1.43 \\
$\mathrm{Mn}$ & 0.13 & 0.20 & 2.42 & 1.53 \\
$\mathrm{~Pb}$ & - & - & 0.15 & - \\
$\mathrm{Cd}$ & - & - & - & - \\
\hline
\end{tabular}

TABLE 5

Metal concentration $\left(\mathrm{mg} \mathrm{kg}^{-1}\right)$ in the post-cropped soil

\begin{tabular}{lcc}
\hline Metal & Protein maize & Non-protein maize \\
\hline $\mathrm{Fe}$ & $91.23 \pm 4.79$ & $81.41 \pm 2.47$ \\
$\mathrm{Zn}$ & $244.30 \pm 77.02$ & $210.35 \pm 78.12$ \\
$\mathrm{Cu}$ & $7.80 \pm 1.35$ & $6.25 \pm 1.35$ \\
$\mathrm{Ni}$ & $13.75 \pm 3.27$ & $9.40 \pm 3.12$ \\
$\mathrm{Mn}$ & $107.78 \pm 3.00$ & $148 \pm 22.13$ \\
$\mathrm{~Pb}$ & $110.73 \pm 28.03$ & $78.43 \pm 19.72$ \\
$\mathrm{Cd}$ & $0.77 \pm 0.24$ & $0.30 \pm 0.20$ \\
\hline
\end{tabular}

\section{Conclusion}

The indiscriminate discharge of untreated waste from metal recycling plant contaminates the soil and that arable crops such as maize cultivated on metal-contaminated soil take up these particulates during their growing periods. These crops pose danger to animals, including humans that ingested them. Also, maize crop is a bioaccumulator of metals in soil. The addition of biochar to soil enhanced the uptake of some heavy metals by maize plant cultivated on metal-contaminated soil, and that protein maize cultivar removes more metals than non-protein maize. 


\section{Acknowledgements}

The financial support for this research by Tertiary Education Trust Fund (TETFUND) through the management of the Obafemi Awolowo University, Ile-Ife, Nigeria is highly appreciated.

\section{REFERENCES}

Adewole, M. B., Adeoye, G. O. \& Sridhar, M. K. C. (2009) Effect of inorganic and organomineral fertilizers on the uptake of selected heavy metals by Helianthus annuus L. and Tithonia diversifolia (Hemsl.) under greenhouse conditions. Toxicological and Environmental Chemistry. 91(5), 963 - 970.

Adeyeye, M. A., Akeredolu, F. A., Sonibare, J. A., Odekanle, E. L. \& Ajala, D. D. (2016) Analysis of total particulate matter from a secondary steel smelting industry. Journal of Atmospheric Pollution 4 (1), 30 - 34.

Amdur, M. O., Doull, J. \& Klaassen, C. D. (1991) Toxicology: The basic science of poisons. Pergamon press, New York, 23, $639-643$.

Bohn, H. L., McNeal, B. L. \& Connor, G. A. O. (1985) Soil Chemistry, Second Edition, Wiley Publication, New York, USA, pp. 210.

Cho-Ruk, K., Kurukote, J., Supprung, P. \& Vetayasuporn, S. (2006) Perennial plants in the phytoremediation of lead contaminated soils. Biotechnology 5(1), 1 - 4 .

Cui, S., Zhou, Q. \& Chao, L. (2007) Potential hyper-accumulation of $\mathrm{Pb}, \mathrm{Zn}, \mathrm{Cu}$ and $\mathrm{Cd}$ in endurant plants distributed in an old smeltery, northeast China. Environmental Geology 51, $1043-1048$.

Epelde, L., Hernandez-Allica, J., Becerril, J. M., Blanco, F. \& Garbisu C. (2008) Effects of chelates on plants and soil microbial community: Comparison of EDTA and EDDS for lead phytoextraction. Science of the Total Environment 401, $21-28$.
Huang, J. W., Chen, J., Berti, W. R. \& Cunningham, S. D. (1997) Phytoremediation of lead-contaminated soils: role of synthetic chelates in lead phytoextraction. Environmental Science and Technology 31, $800-805$.

Ilesanmi, A. O., Adewole, M. B., Odesola, I. F. \& Isichei, A. O. (2016) Production and characterisation of biochar from different farm wastes. African Journal of Sustainable Development. 6(2), $239-250$.

Khairul, N. I., Zaida, R. Y., Amelia, M. S., Nadia, R., Nurul, A. M. R., Elmy, N. O., Nor, A. B., Yushazaziah, M. Y., Rapidah, O. \& Tengku, F. T. Y. (2015) Heavy metal concentration $(\mathrm{Pb}, \mathrm{Cu}, \mathrm{Fe}, \mathrm{Zn}, \mathrm{Ni})$ in plant parts of Zea mays L. cultivated in agricultural area near Alor Gajah, Melaka, Malaysia. American Journal of Environmental Engineering 5 (3A), $8-12$.

Lehmann, J., Rillig, M. C., Thies, J., Masiello, C. A., Hockaday, W. C. \& Crowley, D. (2011) Biochar effects on soil biota - a review. Soil Biology and Biochemistry 43:1812 - 1836.

Lima, I. M., Boykin, D. L., Klasson, K. T. \& Uchimiya, M. (2014) Influence of post-treatment strategies on the properties of activated chars from broiler manure. Chemosphere 95, $96-$ 104.

Liu, W., Shu, W. S. \& Lan, C. Y. (2004) Viola baoshanensis- a plant that hyperaccumulates cadmium. Chinese Science Bulletin 49 (1), $29-32$.

Luo, C. L., Shen, Z. G. \& Li, X. D. (2007) Plant uptake and the leaching of metals during the hot EDDS-enhanced phytoextraction process. International Journal of Phytoremediation 9 , $181-196$.

Masulili, A., Utomo, W. H. \& Syekhfani, M. S. (2010) Rice husk biochar for rice based cropping system in acid soil 1 . The characteristics of rice husk biochar and its influence on 
the properties of acid sulfate soils and rice growth in West Kalimantan, Indonesia. Journal of Agricultural Science 2(1), 39 - 47.

Mohan, D., Pittman, C. U. J., Brcika, M., Smith, F., Yancey, B., Mohammad, J., Steele, P. H., Alexandre-Franco, M. F., Gomez-Serrano, V. \& Gong, H. (2007) Sorption of arsenic, cadmium and lead by chars produced from fast pyrolysis of wood and bark during biooil production. Journal of Colloid Interface Science 310, 57 - 73 .

Murakami, M., Ae, N. \& Ishikawa S. (2007) Phytoextraction of cadmium by rice (Oryza sativa L.), soybean (Glycine max (L.) Merr.), and maize (Zea mays L.). Environmental Pollution 145 (1), $96-103$.

Owoade, O. K., Jegede, O. O., Ayoola, M. A., Fawole, O. G., Bashiru, M. I., Olise F. S. \& Ogundele L. T. (2013) Concentrations of particulate matter from an iron-smelting plant located along a busy highway in Southwestern Nigeria. Ife Journal of Science 15(1), 31 -39 .

Page, A. L., Miller, R. H. \& Keeney, D. R. (1982) Methods of Soil Analysis, Part 2, Chemical and microbiological properties. American Society of Agronomy, Inc., Madison, Wisconsin USA, pp. 556.

Panda, S. K. \& Choudhury, S. (2005) Chromium stress in plants. Brazilian Journal of Plant Physiology 17, $95-102$.

Pirkle, J. L., Kanfmann, R. B., Brody, D. J., Hickman, T., Gunter, E. W. \& Paschal, D. C. (1998): Exposure of the US population to Lead, 1991-1994. Environmental Health Perspectives 106(11), $745-750$.

Prasad, M. N. V. \& Freitas, H. M. D. (2003) Metal hyper-accumulation of plants-Biodiversity prospecting for phytoremediation technology. Electronic Journal of Biotechnology 6(3), $285-321$.
Steiner, C., Glaser, B., Teixeira, W. G., Lehmann, J., Blum, W. E. H. \& Zech, W. (2008) Nitrogen retention and plant uptake on a highly weathered central Amazonian Ferralsol amended with compost and charcoal. Journal of Plant Nutrition and Soil Science 171 (6), 893 - 899.

Tandy, S., Schulin, R. \& Nowack, B. (2006) The influence of EDDS on the uptake of heavymetals in hydroponically grown sunflowers. Chemosphere 62 (9), $1454-1463$.

Tanhuanpaa, P., Kalendar, R., Schulman, A. H. \& Kiviharju, E. (2007) A major gene for grain cadmium accumulation in oat (Avena sativa L.). Genome 50 (6), $588-594$.

Wang, H., Kimberley, M. O. \& Schlegelmilch, M. (2003) Biosolids-derived nitrogen mineralization and transformation in forest soils. Journal of Environmental Quality 32 (5), $1851-1856$.

Wang, M., Zou, J., Duan, X., Jiang, W. \& Liu, D. (2007) Cadmium accumulation and its effects on metal uptake in maize (Zea mays L.). Bioresource Technology 98 (1), 82 - 88.

Yanshan, C., Qingren, W., Yiting, D., Haifeng, L. \& Peter, C. (2004) Enhanced uptake of soil Pb and $\mathrm{Zn}$ by Indian mustard and winter wheat following combined soil application of elemental sulphur and EDTA. Plant and Soil 261 (1\&2), $181-188$.

Yoon, J., Cao, X., Zhou, Q. \& Ma, L. Q. (2006) Accumulation of $\mathrm{Pb}, \mathrm{Cu}$ and $\mathrm{Zn}$ in native plants growing on a contaminated Florida Site. Science of the Total Environment 368 (2), 456 -464 .

Zhuang, P., Yang, Q. W., Wang, H. B. \& Shu, W. S. (2007) Phytoextraction of heavy metals by eight plant species in the field. Water, Air, and Soil Pollution 184 (1-4), 235 - 242. 